\title{
THE IDENTIFICATION OF THE ROMANIAN COMPANIES' MARKETING NEEDS AND MEANS OF COMMUNICATION - A MARKETING RESEARCH -
}

\author{
Iacob Cătoiu ${ }^{1}$ \\ Tudor Edu ${ }^{2}$
}

\begin{abstract}
The marketing needs of the Romanian companies are very diversified, commencing with the research of the needs and demand on the target market, going down to the 4Ps (Product, Price, Promotion and Placement) and their components.

The present marketing research was performed using 11 categories of information sources: specialised publications in marketing; specialised publications in economics; national official statistics; publications of professional associations; publications/web sites of NGOs; reports issued by media institutions and web sites; information provided by specialised institutions in consultancy and marketing research; information provided by individual marketing specialists; information provided by advertising agencies; information provided by the economic sections of the daily newspapers; job web sites.
\end{abstract}

Key words: marketing needs, Romanian companies, secondary data

JEL codes: M31

\section{Introduction}

The Romanian companies have developed tremendously in nearly 20 years of open economy. These companies grew and diversified their businesses and, as a consequence, their marketing needs evolved continuously. In order to determine the current situation of the involvement of marketing in the activity of the Romanian companies a good starting point would be the assessment of the secondary data available on this topic.

In order to perform such a marketing research, the sources of information were grouped in 11 categories: specialised publications in marketing; specialised publications in economics; national official statistics; publications of professional associations; publications/web sites of NGOs; reports issued by media institutions and web sites; information provided by specialised institutions in consultancy and marketing research; information provided by individual marketing specialists; information provided by advertising agencies; information provided by the economic sections of the daily newspapers; job web sites. Out of these 11 categories, 1432 relevant references were identified.

\section{Literature review}

The secondary data already exist. They were collected in research studies performed at a prior date. The secondary data are very useful, because they can provide useful insight on various matters. The conclusions drawn after analyzing secondary data can be sufficient for the researcher. If they are not sufficient, they can represent a starting point for further research studies, such as a focus group, an in-depth interview or a survey.

\footnotetext{
${ }^{1}$ Academy of Economic Studies, Bucharest, Romania, iacob catoiu@yahoo.com

${ }^{2}$ Academy of Economic Studies, Bucharest, Romania, tudoredu@yahoo.com
} 


\section{Research methodology}

1. Research purpose

The identification of the types of needs and means of communication used by the Romanian companies in the field of marketing.

2. Research objectives

- The identification of the Romanian companies' marketing needs in relation to the marketing environment.

- The identification of the Romanian companies' marketing needs in relation to the determination of the buying and consumption behaviour on a particular market.

- The identification of the Romanian companies' marketing needs in relation to their offers sold on a market.

- The identification of the Romanian companies' marketing needs in relation to the setup of their prices.

- The identification of the Romanian companies' marketing needs in relation to the promotional options for their offers.

- The identification of the Romanian companies' marketing needs in relation to the distribution possibilities for their offers.

- The identification of the communication means used by the Romanian companies.

3. Research hypotheses

- The Romanian companies need information about the marketing environment related to:

- the features of the industry/market and tendencies on it

- acquisitions and diversification

- market share

- its employees

- The Romanian companies need information about the buying and consumption behaviour in relation to:

- brand preferences

- attitude towards a brand

- product satisfaction

- buying behaviour

- buying intentions

- brand awareness

- segmentation studies

- The Romanian companies need information regarding their offer which lies in one or more of the following categories:

- concept development and testing

- brand name generation and testing

- test market

- product testing

- package design

- competitors' products

- The Romanian companies need information regarding their prices gathered from:

- cost analysis

- profit analysis

- price flexibility

- demand analysis: market potential; sales potential; sales forecasting

- competitors' price analysis

- The Romanian companies need information regarding their promotional options obtained from:

- the research of the motives which determine the choice for a means of communication 
- the research of the mass communication means

- the research of the advertising message

- the research of the advertising efficiency: before/after broadcasting

- the research of the competitors' advertisements

- the research of the public image

- the research of the sales force's compensation

- the research of the sales force's shares

- the research of the sales force's areas

- the research of promotional instruments such as prizes, coupons etc

- The Romanian companies need information regarding their distribution possibilities obtained from:

- the research of the factory/warehouse location

- the research of the distribution channel's performance

- the research of the distribution channel's coverage

- the research of exports and international trade

- The Romanian companies use a great variety of communication means, such as: newspapers, magazines, TV channels, radio, and online services.

4. Research variables

Table no. 1

\section{Research variables}

\begin{tabular}{|c|c|c|}
\hline Variable & Definition & Directions for research \\
\hline Marketing needs & $\begin{array}{l}\text { The necessity to obtain the } \\
\text { information which will help the } \\
\text { organisation understand the } \\
\text { environment and adapt accordingly } \\
\text { to it }\end{array}$ & $\begin{array}{l}\text { - information about the marketing } \\
\text { environment } \\
\text { - information about the buying and } \\
\text { consumption behaviour } \\
\text { - information about the traded offer } \\
\text { - information about the prices } \\
\text { - information about the promotional } \\
\text { options } \\
\text { - information about the distribution } \\
\text { possibilities } \\
\text { - information about the } \\
\text { communication means }\end{array}$ \\
\hline Marketing environment & $\begin{array}{l}\text { The sum of forces which act in a } \\
\text { direct or indirect manner upon the } \\
\text { organisation }\end{array}$ & $\begin{array}{l}\text { - the features of the industry/market } \\
\text { and tendencies on it } \\
\text { - acquisitions and diversification } \\
\text { - market share } \\
\text { - employees }\end{array}$ \\
\hline Buying and consumption behaviour & $\begin{array}{l}\text { The sum of individual or group } \\
\text { decisions directly connected to the } \\
\text { acquiring and use of goods and } \\
\text { services for the satisfaction of the } \\
\text { current and future needs, including } \\
\text { decision processes which precede } \\
\text { and determine these acts }\end{array}$ & $\begin{array}{l}\text { - brand preferences } \\
\text { - attitude towards a brand } \\
\text { - product satisfaction } \\
\text { - buying behaviour } \\
\text { - buying intentions } \\
\text { - brand awareness } \\
\text { - segmentation studies }\end{array}$ \\
\hline Offer & $\begin{array}{l}\text { The product, service, idea or } \\
\text { combination of these with which } \\
\text { the organisation is present on the } \\
\text { market }\end{array}$ & $\begin{array}{l}\text { - concept development and testing } \\
\text { - brand name generation and testing } \\
\text { - test market } \\
\text { - product testing } \\
\text { - package design } \\
\text { - competitors' products }\end{array}$ \\
\hline Price & $\begin{array}{l}\text { The sum of money which must be } \\
\text { paid by the buyer to the seller in }\end{array}$ & $\begin{array}{l}\text { - cost analysis } \\
\text { - profit analysis }\end{array}$ \\
\hline
\end{tabular}




\begin{tabular}{|c|c|c|}
\hline & order to acquire the offer & $\begin{array}{l}\text { - price flexibility } \\
\text { - demand analysis: market } \\
\text { potential; sales potential; sales } \\
\text { forecasting } \\
\text { - competitors' price analysis }\end{array}$ \\
\hline Means for promoting an offer & $\begin{array}{l}\text { The ways in which the prospect is } \\
\text { informed about the organisation's } \\
\text { offer and persuaded to purchase it }\end{array}$ & $\begin{array}{l}\text { - the research of the motives which } \\
\text { determine the choice for a means of } \\
\text { communication } \\
\text { - the research of the mass } \\
\text { communication means } \\
\text { - the research of the advertising } \\
\text { message } \\
\text { - the research of the advertising } \\
\text { efficiency: before/after } \\
\text { broadcasting } \\
\text { - the research of the competitors' } \\
\text { advertisements } \\
\text { - the research of the public image } \\
\text { - the research of the sales force's } \\
\text { compensation } \\
\text { - the research of the sales force's } \\
\text { shares } \\
\text { - the research of the sales force's } \\
\text { areas } \\
\text { - the research of promotional } \\
\text { instruments such as prizes, coupons } \\
\text { etc }\end{array}$ \\
\hline $\begin{array}{l}\text { Means for placing (distributing) an } \\
\text { offer }\end{array}$ & $\begin{array}{l}\text { The processes and routes through } \\
\text { which an offer reaches a client }\end{array}$ & $\begin{array}{l}\text { - the research of the } \\
\text { factory/warehouse location } \\
\text { - the research of the distribution } \\
\text { channel's performance } \\
\text { - the research of the distribution } \\
\text { channel's coverage } \\
\text { - the research of exports and } \\
\text { international trade }\end{array}$ \\
\hline Means of communication & $\begin{array}{l}\text { The channel used by an } \\
\text { organisation to communicate with } \\
\text { its target }\end{array}$ & $\begin{array}{l}\text { newspapers, magazines, } \mathrm{TV} \\
\text { channels, radio, online services. }\end{array}$ \\
\hline
\end{tabular}

\section{Population}

The researched population is represented by the Romanian organisations. Due to the fact that a broader coverage is desired, the data will be collected without any restrictions tied up to the type and size of these organisations.

6. Secondary data study guide

The study guide was designed in accordance with the research purpose and objectives. This guide was structured in the following chapters:

- business/economic or company research

- product research

- price research

- promotion research

- distribution research

- buying behaviour research

- communication means used by a company 
For each section, the study guide had the following structure:

Tabel no. 2

Study guide

\begin{tabular}{|l|l|l|l|l|l|l|}
\hline Business/economic or company research & $\begin{array}{l}\text { Studies about } \\
\text { the features of the } \\
\text { industry/market } \\
\text { and tendencies on } \\
\text { it }\end{array}$ & $\begin{array}{l}\text { Studies about } \\
\text { acquisitions and } \\
\text { diversification } \\
\text { market share }\end{array}$ & $\begin{array}{l}\text { Studies about } \\
\text { employes }\end{array}$ & Description & Source \\
\hline
\end{tabular}

Tabel no. 3

Study guide

\begin{tabular}{|c|c|c|c|c|c|c|c|c|c|}
\hline Buying behav & our resear & & & & & & & & \\
\hline $\begin{array}{l}\text { Studies } \\
\text { about brand } \\
\text { preferences }\end{array}$ & $\begin{array}{l}\text { Studies } \\
\text { about } \\
\text { attitude } \\
\text { towards } \\
\text { a brand }\end{array}$ & $\begin{array}{l}\text { Studies } \\
\text { about } \\
\text { product } \\
\text { satisfaction }\end{array}$ & $\begin{array}{l}\text { Studies } \\
\text { about } \\
\text { buying } \\
\text { behaviour }\end{array}$ & $\begin{array}{l}\text { Studies } \\
\text { about } \\
\text { buying } \\
\text { intentions }\end{array}$ & $\begin{array}{l}\text { Studies } \\
\text { about } \\
\text { brand } \\
\text { awareness }\end{array}$ & $\begin{array}{l}\text { Segmentation } \\
\text { studies }\end{array}$ & $\underset{9}{\stackrel{\vartheta}{9}}$ & 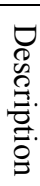 & 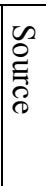 \\
\hline
\end{tabular}

\section{Study guide}

\begin{tabular}{|c|c|c|c|c|c|c|c|c|}
\hline \multicolumn{9}{|l|}{ Product research } \\
\hline $\begin{array}{l}\text { Information } \\
\text { about concept } \\
\text { development } \\
\text { and testing }\end{array}$ & $\begin{array}{l}\text { Information } \\
\text { about brand } \\
\text { name } \\
\text { generation } \\
\text { and testing }\end{array}$ & $\begin{array}{l}\text { Information } \\
\text { about a test } \\
\text { market }\end{array}$ & $\begin{array}{l}\text { Information } \\
\text { about product } \\
\text { testing }\end{array}$ & $\begin{array}{l}\text { Information } \\
\text { about } \\
\text { package } \\
\text { design }\end{array}$ & $\begin{array}{l}\text { Information } \\
\text { about } \\
\text { competitor's } \\
\text { products }\end{array}$ & $\underset{\oplus}{\stackrel{0}{\oplus}}$ & 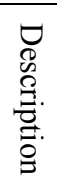 & 告 \\
\hline
\end{tabular}

Tabel no. 5

\section{Study guide}

\begin{tabular}{|l|l|l|l|l|l|l|l|}
\hline $\begin{array}{l}\text { Price research } \\
\begin{array}{l}\text { Information } \\
\text { analysis cost }\end{array}\end{array}$ & $\begin{array}{l}\text { Information } \\
\text { about profit } \\
\text { analysis }\end{array}$ & $\begin{array}{l}\text { Information } \\
\text { about price } \\
\text { flexibility }\end{array}$ & $\begin{array}{l}\text { Information } \\
\text { about } \\
\text { demand } \\
\text { analysis: } \\
\text { market } \\
\text { potential; } \\
\text { sales } \\
\text { potential; } \\
\text { sales } \\
\text { forecasting }\end{array}$ & $\begin{array}{l}\text { Information } \\
\text { about } \\
\text { competitors } \\
\text { price analysis }\end{array}$ & Other & Description & Source \\
& & & & & \\
& & & & & \\
\end{tabular}

Tabel no. 6

Study guide

\begin{tabular}{|l|l|l|l|l|l|l|}
\hline Distribution research \\
\hline $\begin{array}{l}\text { Studies about } \\
\text { factory/warehouse } \\
\text { location }\end{array}$ & $\begin{array}{l}\text { Studies about } \\
\text { distribution } \\
\text { channel's } \\
\text { performance }\end{array}$ & $\begin{array}{l}\text { Studies about } \\
\text { distribution } \\
\text { channel's } \\
\text { coverage }\end{array}$ & $\begin{array}{l}\text { Studies about } \\
\text { exports and } \\
\text { international } \\
\text { trade }\end{array}$ & Other & Description & Source \\
\hline
\end{tabular}

Tabel no. 7 


\section{Study guide}

\begin{tabular}{|c|c|c|c|c|c|}
\hline \multicolumn{6}{|c|}{ Promotion research - table 1} \\
\hline $\begin{array}{l}\text { Studies about the } \\
\text { motives which } \\
\text { determine the } \\
\text { choice for a } \\
\text { means of } \\
\text { communication }\end{array}$ & $\begin{array}{l}\text { Studies about the } \\
\text { mass } \\
\text { communication } \\
\text { means }\end{array}$ & $\begin{array}{l}\text { Studies about the } \\
\text { advertising } \\
\text { message }\end{array}$ & $\begin{array}{l}\text { Studies about the } \\
\text { advertising } \\
\text { efficiency: } \\
\text { before/after } \\
\text { broadcasting }\end{array}$ & $\begin{array}{l}\text { Studies about the } \\
\text { competitors' } \\
\text { advertisements }\end{array}$ & $\begin{array}{l}\text { Studies about } \\
\text { the public } \\
\text { image }\end{array}$ \\
\hline
\end{tabular}

Tabel no. 8

Study guide

\begin{tabular}{|l|l|l|l|l|l|l|}
\hline \multicolumn{2}{|l|}{ Promotion research - table 2 } & Description & Source \\
\hline $\begin{array}{l}\text { Studies about } \\
\text { the sales }\end{array}$ & $\begin{array}{l}\text { Studies about } \\
\text { the sales } \\
\text { force's } \\
\text { compensation }\end{array}$ & $\begin{array}{l}\text { Studies about } \\
\text { the sales } \\
\text { force's areas }\end{array}$ & $\begin{array}{l}\text { Studies about } \\
\text { promotional } \\
\text { instruments } \\
\text { such as prizes, } \\
\text { coupons etc }\end{array}$ & & Other & \\
& & & & & \\
\end{tabular}

Tabel no. 9

Study guide

\begin{tabular}{|l|l|l|}
\hline Communication means used by a company & Description & Source \\
\hline \multicolumn{2}{|l}{} \\
\hline
\end{tabular}

7. Sources of secondary data

The secondary data sources were structured in several chapters to facilitate the study:

1. Specialised publications in marketing

2. Specialised publications in economics

3. National official statistics

4. Publications of professional associations

5. Publications/web sites of NGOs

6. Reports issued by media institutions and web sites

7. Information provided by specialised institutions in consultancy and marketing research

8. Information provided by individual marketing specialists

9. Information provided by advertising agencies

10. Information provided by the economic sections of the daily newspapers

11. Job web sites

8. Research conclusions

After analyzing the secondary data sources structured in: specialised publications in marketing; specialised publications in economics; national official statistics; publications of professional associations; publications/web sites of NGOs; reports issued by media institutions and web sites; information provided by specialised institutions in consultancy and marketing research; information provided by individual marketing specialists; information provided by advertising agencies; information provided by the economic sections of the daily newspapers; job web sites1432 relevant references were identified.

In order to match these references with the research objectives, each objective was analyzed.

Objective no. 1- The identification of the Romanian companies' marketing needs in relation to the marketing environment. 
After analyzing the data it was concluded that this objective had been accomplished. In this regard it was found that the Romanian companies' marketing needs related to the environment could be grouped mainly in;

- the necessity to study the features and tendencies of a market/industry;

- the necessity to study acquisitions and diversifications;

- the necessity to study market shares;

- the necessity to study the employees (their morale, the internal communication etc.).

Also other marketing needs pertaining to this objective were discovered. These needs could be grouped in needs for:

- information about the recession of the European economy;

- information about countermeasure actions regarding the financial crisis;

- macroeconomic studies;

- inter-industry studies;

- auditing studies of the managerial activities;

- studies about mergers between Romanian companies.

The hypothesis formulated for this objective was partially confirmed because other needs were found besides the ones asserted in this hypothesis.

Objective no. 2- The identification of the Romanian companies' marketing needs in relation to the determination of the buying and consumption behaviour on a particular market.

The analysis of the collected data concluded the accomplishment of this objective. The Romanian companies' marketing needs related to the buying and consumption behaviour could be grouped mainly in needs for:

- information about brand preferences;

- information about the attitude towards a brand;

- information about product satisfaction;

- information about buying behaviour;

- information about buying intentions;

- information about brand awareness;

- information about segmentation studies.

Other marketing needs pertaining to this section were identified and grouped in needs for:

- studying the buyer-supplier relationship and ways in which a supplier is selected;

- studying the consumer and his/her evolution;

- identification of the criteria used to direct the consumer towards the discount stores;

- correlation of factors influencing the marketing environment and consumer behaviour;

- correlation of the current economic situation with changes of the buying behaviour.

The hypothesis formulated for this objective was partially confirmed because other needs were found besides the ones asserted in this hypothesis.

Objective no. 3- The identification of the Romanian companies' marketing needs in relation to their offers sold on a market.

Based on the analysis of the collected data the third objective was accomplished. The marketing needs of the Romanian companies related to their offers were grouped partially in needs for:

- concept development and testing;

- brand name generation and testing; 
- test market analysis;

- product testing;

- package design;

- competitors' products.

to:

Other marketing needs related to the offer were identified. These marketing needs referred

- brand management;

- branding projects;

- brand reinforcement;

- brand strategy;

- local product concept;

- product certification;

- brand repositioning;

- brand usage studies;

- brand change;

- brand loyalty;

- brand image assessment;

- brand map;

- ideal brand;

- brand strategy assessment;

- brand performance;

- brand research;

- brand identity;

- personal brand;

- exclusive brand.

The hypothesis formulated for this objective was partially confirmed because other needs were found besides the ones asserted in this hypothesis.

Objective no. 4- The identification of the Romanian companies' marketing needs in relation to the setup of their prices.

The analysis of the collected data concluded the accomplishment of the $4^{\text {th }}$ objective. The price related marketing needs of the Romanian companies lay, mainly, within the categories mentioned below:

- cost analysis;

- profit analysis;

- price flexibility;

- demand analysis: market potential; sales potential; sales forecasting;

- competitors' price analysis.

Other price related marketing needs were identified. These needs refer to the following concepts:

- the concept of quality/price ratio;

- the concept of preset price;

- the concept of preferential prices;

- the concept of price level;

- the concept of purchasing power;

- the concept of penetration prices;

- the concept of top load prices;

- the concept of product line price;

- the concept of reinvested profit;

- the concept of hedging operations; 
- the concept of reference price.

The hypothesis formulated for this objective was partially confirmed because other needs were found besides the ones asserted in this hypothesis.

Objective no. 5- The identification of the Romanian companies' marketing needs in relation to the promotional options for their offers.

The analysis of the collected data concluded the accomplishment of the $5^{\text {th }}$ objective. The Romanian companies had marketing needs related to the promotional activities mainly drawn from:

- the research of the motives which determine the choice for a means of communication;

- the research of the mass communication means;

- the research of the advertising message;

- the research of the advertising efficiency: before/after broadcasting;

- the research of the competitors' advertisements;

- the research of the public image;

- the research of the sales force's compensation;

- the research of the sales force's shares;

- the research of the sales force's areas;

- the research of promotional instruments such as prizes, coupons etc

Other marketing needs pertaining to this section were identified and grouped in the following topics:

- viral marketing- the advertising impact;

- communication strategies;

- unconventional advertising;

- movies as mega-advertising means;

- brand and urban artistic events association and outdoor media forms;

- online PR and consultancy;

- brand engagement PR;

- commercial promotion through virtual exhibitions;

- brain reaction analysis to advertisements using scanning devices;

- good advertising and bad product situations.

The hypothesis formulated for this objective was partially confirmed because other needs were found besides the ones asserted in this hypothesis.

Objective no. 6- The identification of the Romanian companies' marketing needs in relation to the distribution possibilities for their offers.

Based on the analysis of the collected data, the $6^{\text {th }}$ objective was accomplished. The Romanian companies had marketing needs pertaining to distribution which could be grouped mainly in the following research studies:

- research of the factory/warehouse location;

- research of the distribution channel's performance;

- research of the distribution channel's coverage;

- research of exports and international trade;

Also, other needs were identified. These needs were grouped in several sections;

- manufacturer-retailer relationship;

- new distribution channels;

- distribution adaptation strategies;

- classic and online distribution strategies;

- logistics. 
The hypothesis formulated for this objective was partially confirmed because other needs were found besides the ones asserted in this hypothesis.

Objective no. 7- The identification of the communication means used by the Romanian companies.

Based on the analysis of the collected data, the following communication means were identified:

- daily newspapers;

- specialised publications;

- TV channels;

- Radio;

- web sites;

- online search engines;

- e-mails;

- short messages;

- multimedia messages;

- sales force;

- direct response letters;

- newsletters;

- outdoor;

- transit;

- point-of-sale display;

- promotional catalogues;

- brochures;

- instructions;

- flyers.

The hypothesis formulated for this objective was partially confirmed because other needs were found besides the ones asserted in this hypothesis.

\section{Conclusions}

It can be concluded that the marketing needs of the Romanian companies are very diversified, commencing with the research of the needs and demand on the target market, going down to the 4Ps (Product, Price, Promotion and Placement) and their components. A company's marketing needs vary according to the company's size, market and objectives.

\section{References}

1. Cătoiu I. (coord.), 2009. Cercetari de Marketing. Tratat. Uranus Publishing House. Bucureşti.

2. Kotler Ph., Armstrong G., 2008. Principles of Marketing $12^{\text {th }}$ ed., Pearson Ed., NJ.

3. Kotler Ph., Keller K. L., 2006. Marketing Management $12^{\text {th }}$ ed., Pearson Ed., NJ. 